\title{
Six Decades of the Second Food Regime in Iran, the Trajectory of Iranian National Food Regime
}

\author{
Mozhdeh Babagoli, Satoshi Ikeda \\ Department of Sociology and Anthropology, Concordia University, Montreal, Canada \\ Email: mozhdeh.babagoli@mail.concordia.ca
}

How to cite this paper: Babagoli, M. and Ikeda, S. (2019) Six Decades of the Second Food Regime in Iran, the Trajectory of Iranian National Food Regime. Open Journal of Social Sciences, 7, 191-205. https://doi.org/10.4236/jss.2019.76016

Received: May 28, 2019

Accepted: June 24, 2019

Published: June 27, 2019

Copyright $\odot 2019$ by author(s) and Scientific Research Publishing Inc. This work is licensed under the Creative Commons Attribution International License (CC BY 4.0).

http://creativecommons.org/licenses/by/4.0/ (c) (i) Open Access

\begin{abstract}
Since the 1980s, international corporations have curtailed the autonomy of national states and have developed a new form of global food regime. Although the nouvelle regime promoted a new level of economic exploitation of the Global South, there are still some countries which resist the globalist corporations' penetration into their economies. This paper argues that the Iranian economy, due to a variety of reasons which were not necessarily endogenous, such as international sanctions, could not have been conquered by corporations. The Iranian revolutionary regime which had come up with the slogans of "Achieving Self-Sufficiency" and "Standing against Global Imperialism," stepped towards liberalization and privatization in less than ten years. However, the political sensitivity of food, as well as various forms of sanctions against Iran, did not provide the possibility of complete integration of Iranian food sector into the global free trade system. Even the IMF's prescription of economic reform did not lead to much deregulation, and just expanded the quasi-state sector of the Iranian economy. Therefore, the national regime, which is an evolved form of the former food regime, still overshadows the agricultural economy of Iran. The recent post-deal era also does not seem to bring a serious threat to the Iranian national food regime.
\end{abstract}

\section{Keywords}

Food Politics, Global Food System, National Food Regime, Food-Aid Programs, Liberalization

\section{Introduction to Food Regimes}

About six decades have passed since the Shah's wide-ranging land reform and the beginning of food-aid programs, carried out to improve food security among Iranians. Since then, many domestic and international factors have influenced 
Iranian agro-food system. In these few decades, Iran has gone through a political revolution, an 8-year war and decades of international sanctions in the context of a neo-liberal world, and still been waiting for qualification for WTO membership [1] [2]. This paper aims to investigate the trajectory of Iranian agro-food system since the Shah's agrarian reforms. To gain a comprehensive understanding of the Iranian agricultural order in the aforementioned period, we need a theoretical concept which enables us to historicize the Iranian food politics and relations. We believe that Food regime, as a historical concept and a method of interpreting the contradictory underlying agro-food relations [3], assists us in reaching this goal. We apply this concept to study the changes in the Iranian agro-food system during the Shah, and the developments take place after the formation of the Islamic Republic.

The concept of "food regime" was formulated for the first time by Harriet Friedmann (1987) to explain the rise and demise of the US food-aid programs [4]. McMichael (2013), then, develops the concept of "food regime," to distinguish three historical food systems whereby specific agro-food rules regulate the process of food production and consumption within the world system. In the late nineteenth century, with the expansion of railways and maritime transports, the dominant British empire was able to combine colonial tropical agriculture with the developing capitalist world system [4]. The proliferation of steam power assisted the formation of the first global food regime which lasted from the 1870 s to 1930s. In the previous ancient trade-networks, such as Silk Road, the long-distance traded agro-foods like tea, sugar, and spices remained expensive luxury goods used as a marker of social distinction, but they started to be democratized in Europe through the frontier explorations. During the first food regime, cheap grains and livestock exports from settler states fed the workforce of industrializing nations "in Europe, absorbed capital and their surplus population via migration and constituted vital demand for their manufactured exports" [5] [6]. Non-settler regions like the Middle East also substantially contributed to the network. Most parts of the Middle East including current Iran were never formally colonized, but it was part of the "Britain's workshop of the world" as a supplier of tropical goods like silk and cotton while still regionally self-sufficient in staples [6].

After World War II and the demise of imperial relations through anti-colonial revolutions, the United States topped a system of national states [7]. Friedmann (2016) and McMichael (2013) argue that the shift in the international power order profoundly transformed the global food system. The second food regime, which represented an international political-economic alliance, was formed in the 1950s. The US regime unified Western Bloc agro-economics during the Cold War by granting food-aid to its allies, especially in the Global South. Development states instituted land reforms and adopted Green Revolution technologies to quell peasant unrest and to integrate rural areas into the capitalist market [5] [7]. These changes led to a massive rural-urban migration wave and expansion of the urban workforce. Economists such as Rostow (1990) discussed that sur- 
plus rural labor force created through the industrialization of the agriculture would be transferred to the industry to provide a boost to the economy [8] [9].

McMichael argues that in the 1980s with the collapse of Keynesian ideology and through the prevalence of liberalization practices and international institutions, the global agro-economics also considerably transformed. He points out that the current food regime, which is under the domination of corporations (1980s-2000s), has deepened the process of accumulation. The corporate regime, a primary part of "neoliberal globalization project," has regarded the market as the most efficient means of achieving food security [5] [10]. McMichael identifies the corporate food regime as the historical evolution of colonial relations between the Global North and its global frontiers. Despite the shift from Keynesianism to neoliberalism in the 1980s, a blend of the two approaches has been seen at the national level based on the level of integration into the free market. In some countries, government safety net programs still prevent integration into the new global food regime. Iran, with one of the lowest Economic Freedom indices, ${ }^{1}$ is one of the nations that have resisted the domination of the corporation over their economies.

Iranian food aid system has, to some extent, maintained its continuity since the Pahlavi era, while political-economic discourse changed radically after the revolution. The discursive differences and the increasing importance of self-sufficiency policies in revolutionary economy have led many scholars, such as Chaifetz \& Jagger (2014), Salami et al. (2013) Babar, 2014; Kamrava et al. (2012) and Amid (2007), to conclude a shift in the Iranian agricultural system [11] [12] [13] [14] [15]. We believe that despite the significant changes in national policies as well as the fundamental changes in global trade relations, the Islamic Republic's and Pahlavi's food policies share certain similarities. Many of the post-revolution food policies are evolved forms of the Shah's policies, especially following the "White Revolution" era. This essay aims to challenge the assumption of substantial differences between Pre- and Post-Revolution agrarian systems by taking the similarities into consideration and to explains how the Shah's agro-food decisions and policies have continued after the establishment of the Islamic Republic. Food regime, a concept examining the domestic agro-food relations within the international order, assists us in studying the persistence of Iranian national food system. Also, this study can make a theoretical contribution to the broader analysis of international [agricultural] development by applying the food-regimes conceptual model and exploring the scope of applicability of the third food regime.

\section{Food Regimes in Iran}

A brief acquaintance with the Iranian and the surrounding region's agro-food economies provides a better understanding of the development of current Ira-

${ }^{1}$ Ranked $171^{\text {th }}$ among 178 and $155^{\text {th }}$ among 180 countries respectively in 2015 and 2019 . Also see https://www.heritage.org/index/country/iran. 
nian food regime and the significance of the changes that occurred in the early 1960s. The first food regime coincided with the late Qajar (1794-1925) and the early Pahlavi era in Iran. Despite political turmoil, Iran was still a major exporter of cotton, tobacco, and rice in the region. India (Great Britain), the Ottoman Empire and Egypt were the main importers of tobacco from Iran [16] [17]. Although the Pébrine outbreak in the mid-nineteenth century cut silk production to one-third, silk was still one of Iran's profitable exports to France, Russia and the Ottoman Empire. In the middle of the nineteenth century, Iran faced a widespread famine due to the inefficiency of the Shah, courtiers, and Khans. The increase in staple food exports (to redress the balance of trade), fallowing the lords' land which had gone under cultivation at the time of the former prime minister (Amir Kabir), in addition to a boost in the area under opium cultivation, presented the country with a cereal crisis for three years (1869-72) and led to several riots in different parts of Iran [16] [18].

Though the conditions differed from one country to another during the Britain food regime, the Middle East was still self-sufficient in staple foods. Some parts of the Middle East, the region which is now the first importer of globally traded grains ${ }^{2}$, had great export capacities for cereals. While the Gulf imported grains, Iraq, Egypt, and Syria exported their surpluses. It should be noted, despite the regional self-sufficiency, in terms of food, during the first regime, "weak domestic industries failed to give a strong demand impetus for agriculture and enhance its value chain" [6].

\section{Second Food Regime in Iran}

The second food regime began with the implementation of the first development plan (1949-56) under the Shah [19] and culminated in the White Revolution ${ }^{3}$ (1963-78) and land reform. In the first development plan, 25 percent of the total budget was allocated to the agricultural sector, which was mostly allotted to rural infrastructure, especially irrigation systems [20].

The Shah, with the support of the US, launched a far-reaching series of reforms known as the White Revolution (Revolution of the King and the People) in 1963 that lasted for 15 years [21]. Land reformaimed at improving social justice and resolving "the class conflict," as the Shah emphasized. By redistributing the land, the Shah implicitly tended to curtail the power of landlords and provide greater legitimacy among the peasants and working-class people [22]. Despite the common critiques on the implementation of land reform and its devastating impact on agricultural production, the production of primary agricultural produce increased during those years. The achieved agricultural growth was, however, lower than the predicted rate in development plans [20] [23]. ${ }^{4}$ The production level was not also compatible with high population growth, which was the result of increasing access to health care after the establishment of the ${ }^{2}$ It imports a third of globally traded grains.

${ }^{3}$ It was part of the Green Revolution took place in the 1930s-70s.

${ }^{4}$ Also see Appendix A. 
health and literacy corps.

The population soared by $30 \%$ in a decade, from 1966 to 1976 . This coincided with the flood of cheap grains to the US allies in the Global South under the US food-aid programs. The government, which could not meet the increasing demands of people, augmented the import of staples. ${ }^{5}$ It was not the only reasoning behind the rising imports in that period. In the last years of the Pahlavi dynasty, the discontent of merchants (bōzōris) and strikes led to a rise in the prices of basic commodities. To prevent bread riots and also to break the monopoly of bāzōris, the Shah increased the cereal imports from the US [24]. The affordable food was distributed through newly established national supermarket chains which rapidly faced the public reception.

\section{Facing the Third Food Regime?}

Though many countries have been swallowed up by the third food regime, it seems that some nations with closer economic systems such as Iran and Libya ${ }^{6}$ are still outside of the circle. The presence of corporations in these countries is limited, and trade barriers are imposed to curb free trade competition in favor of local procedures. Their regulated food systems, in addition to providing different forms of subsidies, retain strong oversight of pricing, as well as food exports and imports. There were some other countries, such as Iraq and Egypt, resisted the corporations until the early twenty-first century. Eventually, they went through structural reforms under the pressure of WTO and IMF. Due to the current political situation in Libya, the interest in and speed of deregulation have increased, but the question is what path Iranian agro-economy is taking? In the following section, the barriers to Iran's entry into the third era will be discussed, and the pre- and post-revolutionary conditions will be compared.

\subsection{Pre-Revolution Era}

In the agricultural parts of the first and second development plans, the government gave its main priority to the industrialization of agriculture through the provision of modern irrigation systems, the purchase of machinery and the development of barren land. The third development plan, which coincided with the White Revolution, was based on land reform [20]. In fact, the land reform's goals were aligned with the implementation of Kennedy's "Alliance for Progress" to prevent anti-US movements and popular uprisings in the Global South [25] [26]. The emergence of social justice and anti-colonial movements all around the Global South after World War had led to the recognition of international and intra-national wealth gaps and economic inequalities as potential destabilizers of the world order. Northern economists, along with their Southern counterparts, mobilized under the Development Campaign to combat poverty and underdevelopment. [27] [28] [29] [30].

${ }^{5}$ Also see Appendix B.

${ }^{6}$ Ranked 176th among 179 based on Economic Freedom Index in 2012. 
The significant share of allocated budget to Iranian reforms was supposed to be achieved from oil revenues. Although the third development plan budget predicted that 55 percent of expenditures would be paid from petroleum revenues, the share of oil income soared to 80 percent in the last year of the program. The fourth and fifth development plans, coinciding with the increase in global oil prices, in which the share of the agricultural expenditure fell sharply (respectively 8.58 and 6.2 percent), mainly focused on industry and consequently [20].

The rising oil prices and the government's misplaced priorities led to an uneven development across the country and caused a significant urban-rural disparity, which was also prominent in the formation of Iranian revolutionary. Advanced industrialization as the primary goal of the fourth and fifth development plans resulted in a flood of rural migrants to the cities. The massive flows of rural-urban migration and rapid slumization and ruralization of major Iranian cities forced Pahlavi's planners to set achieving the "full or relative self-sufficiency" and alleviating the rural and urban income disparity as primary objectives of the sixth plan. This national plan started the discourse of self-sufficiency in Iran. However, due to the 1979 revolution, "this plan was never implemented" [20] [25] [31].

The unprecedented increase in oil prices assisted the formation of a state bourgeoisie and quasi-state bourgeoisie. The Shah intended to achieve more autonomy from traditional merchants. Hetried to undermine their power and influence among the masses by opening the large low-priced department stores and starting up the quasi-national corporations [24]. Thus, national corporations took charge of a large part of the import and distribution networks of food and appliances. The state-run economy could persist even after the revolution.

\subsection{Post-Revolution Era}

\section{During the Iraq-Iran War}

The rise of Reaganomics in the early 1980s, prompting deregulation at the national and international levels, facilitated the economies' integration in the global market. Many nations were pursuing austerity policies, but Iran took a different path. After the revolution, Iranian state economy expanded through nationalization of industry ${ }^{7}$ and natural resources, land reform programs (through the seizure and redistribution of agricultural land) [20] [32] and also due to economic isolation caused by International sanctions.

Although the Shah's intensive socio-economic plan to prevent nationalist and socialist subversive movements did not succeed, the land reform and nationalization of resources (carried out under the Shah's White Revolution) proceeded through Iranian revolutionary movement. During the Iran-Iraq war, because of the international restrictions on the sale of Iranian oil and consequent food shortages, the government attempted to create food security by distributing food ${ }^{7}$ For example, 28 private banks and automobile and metal factories and the properties of 51 Iranian aristocrats and bourgeois and their first-degree relatives were nationalized. 
coupons (for sugar, rice, margarine, meat, etc.) ${ }^{8}$. This necessary increase in food rations, which aimed to curb accelerating inflation and ensure price stability, deepened the Iranian state-run economy, especially the agro-food sector. The rations were distributed until the late Ahmadinejad era (2010) and then transformed into "the basket of goods."

From the first days after the revolution, self-sufficiency has been announced as one of the main goals of the new regime. Following of the pre-revolution policies, the government put wheat self-sufficiency on its agenda [11] [15]. The first post-revolution development plan prioritizes the "transformation of the oil-based economy to non-oil" economy [20]. It was supposed to be achieved by investing in rural development and through agricultural self-sufficiency. The plan did not gain parliamentary approval, and the first development program was finally implemented ten years after the revolution.

The new political regime, which was formed by Ayatollah Khomeini with the direct support of bazaar merchants, purged the parliament and other decision-making areas of the leftists. The consequent rise in power of the liberal politicians posed the main obstacle to the implementation of the first post-revolution development plan. Despite the opposition of the liberal groups to the non-oil economic plan, the international sanctions and severe shortages of food and medicines kept the national food-aid programs still necessary. While the new political structure was not stabilized, the strategic importance of food and agriculture led the government to control food distribution and pricing and to monitor the activities of international and large domestic agribusinesses.

\section{$>$ After the Ceasefire}

It was after the war ${ }^{10}$ that Iran started adopting privatization and deregulation policies. The same approach was taken in many countries (including England, Turkey, and so on) nearly a decade ago. Since the first implemented post-revolution development plan in the postwar reconstruction era, economic liberalization and privatization have been regarded as the effective strategies for achieving economic growth [20], but have still not been realized.

In the postwar era, with a new interpretation of Article $44^{11}$ of the Iranian Constitution, according to which nationalization of industries and banks had taken place, several private banks were inaugurated, and some national company stocks were sold to the private sector. However, the Iranian economy remained rather different. The massive nationalization of industry and commerce and the establishment of the state-owned enterprises, as well as heavy dependence on oil

\footnotetext{
${ }^{8}$ Before the war, rice was the staple food of the northern Iranian. Other Iranians' diet and preference gradually changed by increasing accessibility to the rice at that time. Then, the rising demand for rice surged its import after the war.

${ }^{9}$ With the intensification of international sanctions against Iran over the past year, the issue of the necessity of a more comprehensive ration system has been raised again in the Iranian parliament.

${ }^{10}$ Iran-Iraq war ended in August 1988.

${ }^{11}$ Also see The General Policies Pertaining to Principle 44 of the Constitution of the Islamic Republic of Iran at

http://irandataportal.syr.edu/the-general-policies-pertaining-to-principle-44-of-the-constitution-ofthe-islamic-republic-of-iran.
} 
revenues, provided the state and affiliated groups with a huge amount of finance and secured their primary position in the national economy. Although the Iranian government, under the influence of global neoliberalism, has set privatization and increasing foreign investment as its major goals, foreign embargos periodically have slowed down or accelerated the process. Many state-owned enterprises (including the public companies and banks), impacted by international embargos, needed to be transferred to quasi-state sector to bypass the sanctions. A significant part of the national bourgeoisie (who were often aristocrats) had left the country in the early post-revolution years. The post-war bourgeoisie, formed during the reconstruction era, never established an independent identity from state institutions.

Despite all this, the food industries have had more stable conditions. The national companies are still the biggest dairy and agricultural producers. In the past 40 years, though self-sufficiency has become the regime's catchphrase, there has been no long-term plan for reaching a non-oil dependent agriculture basis. The agricultural self-sufficiency in general, or wheat self-sufficiency in particular, is never sustained. Perhaps the primary reason is that Iran's planning and economic priorities are usually temporary and reactive.

Same as the 30-year plan for privatization, self-sufficiency has always been influenced by global trends. The national self-sufficiency policy, such as the liberalization and privatization plan, rather than being based on long-term plans, has been affected by external factors including oil prices and international sanctions. For example, in the Khatami era of very low oil prices (average price of less than 20 USD per barrel), Iran temporarily achieved relative self-sufficiency in wheat production [33]. With rising oil prices and the consequent increase in the purchasing power of the government, the following administration (like the Shah) increased import volumes to bring satisfaction to a large section of society by holding down the food prices.

The implementation of a targeted subsidy plan (2010), as a key part of the Iranian economic reform plan, was one of the most critical changes took place in the Iranian economy in the past ten years. The same plans have been promoted by the WTO in several countries since the late twentieth century. In Algeria, under the pretext that "the subsidies benefit[ed] the rich more than the poor," food subsidies were restricted or eliminated in the 1990s [34]. Such as Iran, after the execution of the targeted subsidy plan, the national currency was devalued by approximately 200 percent [35]. According to the Central Bank of Iran, by the implementation of the subsidy reform plan, the Gini coefficient only dropped for a year from 0.3813 to 0.3750 , and in the following years increased steadily [36] [37]. The widening class gap has undermined food security in Iran, as in Egypt and Iraq, which had followed the same path before. The number of malnourished people has soared in all these countries [38] [39].

In Iranian subsidy reform plan, the government cut the food and energy carrier' subsidies and distributed a cash subsidy instead. Despite high inflation and 
the steady increase in national fuel prices, the amount of cash subsidy has remained constant in the past nine years. Prior to the execution of the Iranian targeted subsidy plan and cash subsidy program (2010), which are very similar to Libyan parliament's cash subsidy plan for the next years, the low price of wheat had been seen as the main obstacle in achieving self-sufficiency in wheat production and sustaining a balance between domestic production and demand. Like the Libyan parliament, Iranian government aimed to reduce fuel smuggling and prevent waste of resources by offering a cash subsidy plan. Contrary to expectations, energy consumption declined for a few months and then gained an upward trend. The petrol consumption in Iran, which was 62.8 million liters per day before the subsidy reform plan, raised to 70 million per day after three years, in 2013 [40] [41]. Depreciation of Iranian Rial, which was a result of the implementation of the targeted subsidy plan and the intensification of international sanctions, had significant impacts on achieving the government's envisaged objectives. Prior to the subsidy reform plan, the price of petrol in Iran was about 16 percent of the world price, and it rose to 47 percent of the global price immediately after the implementation of the plan. However, due to the devaluation of the Rail, the price declined to 16 percent of the world price within three years [41].

Stopping the smuggling of subsidized bread and fuel was one of the reasoning behind the targeted subsidy plan. However, due to the fall of Iranian Rial and the sharp difference in prices in Iran and neighboring countries (such as Turkey and Iraq) fuel and bread smuggling, it is still a lucrative business. Also, government expenditure on providing wheat and flour supplies did not decline as a result of the devaluation of the national currency and the increase in wheat imports.

Economic reform and targeted subsidy plans are the IMF prescriptions for the Global South countries such as Algeria, Egypt, and Iran. These plans pave the way for their integration into the competitive global economy and facilitate the entry of corporations into these countries. However, it seems that the Iranian version of the plan has not been very successful. This plan, not only did not meet the goals announced by the government, including narrowing the class gap and gaining the self-sufficiency in grains, but also did not provide the desired objectives of the IMF. Due to the sanctions, state control over the food industries did not decline, and the quasi-state sector, which has been responsible for food imports expanded in this era.

Two years ago, it was obscure (still unclear) that how the Iranian food system would change in the post-deal era. Some corporations saw Iran as virgin territory to conquer. Nevertheless, after the United States' unilateral withdrawal from Iranian nuclear deal and extension of American sanctions against Iran, the future of corporations' involvement seems obscure and unpredictable. Even so, the fate of the companies that exported cheap, genetically modified food (including cereals) in this brief opportunity after the deal is uncertain. We think it is still possible that corporate genetically modified products (like bred plants) are pur- 
chased to be copied and mass-produced by national companies. It seems that much hope cannot be pinned on a long-standing relationship between corporations and Iranian agro-food economy. The isolation of its economy makes it is easier for Iran to avoid adhering to legal requirements of agricultural corporations and allows the Iranian farmers to indigenize agriculture through traditional breeding methods. Climate change (deforestation, drought, and soil erosion) is another reason why Iran's agriculture is to be sustainable, and corporation relations should be avoided. When improvement cannot be initiated from outside, endogenous development is the only solution. In this context, many alternative practices are emerging.

With last year's high inflation and depreciation of the national currency (as a result of the decline in foreign exchange earnings due to imposing further restrictions on Iranian exports, systemic corruption and psychological effects of sanctions) imported products lose the competition to cheaper domestic ones. Also, this destabilized economic environment reinforces the economic resistance and agricultural self-sufficiency discourses. While class-conflicts are growing ${ }^{12}$ and political unrests are spreading over the region, economic resistance needs be accompanied by class-gap narrowing policy. The Iranian parliament has proposed an income equalization program for following years and the state has admitted returning to a rationed economy. However, some scholars regard the structural changes and shocks in the Iranian economy, caused by soaring inflation and a decrease in labor cost, as a part of "shock therapy" doctrine [42], followed since Ahmadinejad.

\section{Conclusions}

Iran, which has never been directly colonized, was generally self-sufficient in the production of staples and was known as a major exporter of cotton, tobacco, and rice before the US food-aid regime. During the second food regime, Iran took up America's suggestion of agrarian reform as a means to pre-empt the Red peasant revolution. The implementation of land reform cut down the agricultural yield in some regions and boosted the crops in other regions. The division of land and loss of old social relations harmed production in many areas. On the other hand, the restoration of barren lands and the agricultural mechanization led to a rise in total production. The slow-rising agricultural yield was still unable to meet the rapid population growth. The gap between domestic production and increasing demands was filled with cheap price food imported from the US, led to an increase in Iran's dependence on imports from America.

The rising oil prices in the 1970s, made the Shah invest more in the agricultural sector to re-establish self-sufficiency. This doctrine has also been proceeded in the post-revolution era, though never fully achieved. Government support of farmers has continuously continued. Even after the implementation of the targeted subsidy plan which aimed to bring staple food prices close to the world 
prices, it is still vital for the government to buy the cereals from farmers at a guaranteed price and to offer them to the consumers at lower prices.

After the revolution, Iranian production arena has been dominated by the discourse of self-sufficiency. For decades, self-sufficiency in staples has been on the agenda of states, but in many cases, the provision of affordable food is prioritized to prevent working-class uprisings. In times of high oil prices, administrations have tried to increase their popularity by keeping prices low through importing cheap food. This policy change has repeatedly damaged domestic agriculture and moved Iran away from self-sufficiency.

In this essay, it was discussed that targeted subsidy and economic reform plans which were set by the IMF as prerequisites for Iran's entry to the competitive market, not only did not cause deregulation but developed the current Iranian [quasi] state-run economy. The food industry's dependence on the state, which formed due to the Shah's tendency toward achieving independence from the Bazaar and a consequent increase in imports in the late Pahlavi era, deepened in the early post-revolution years as a result of the limitations in food supplies. Although the government adopted liberalization and privatization policies after the war, the food industry was one of the last sectors to undergo "surgery" due to the high political importance of food and nutritional security. According to the IMF report [43], economic surgery was not successful and formed other shapes of regulations. Moreover, government spending on grain supplies rose as a result of the depreciation of the Iranian currency.

If we compare the Iranian food system with other Global South countries, its agro-food economic situation could be assessed somewhere between Egypt and Libya. Libya moves toward subsidy reform after a food and energy crisis, while Egypt cut the food subsidies in the late twentieth century and opened its doors to the corporations in the early twenty-first century. The Iranian economic reconstruction, such as the similar economic reforms took place in Egypt and Iraq, has reinforced class inequality and expanded food insecurity. The implementation of a targeted subsidy plan, coupled with the intensification of sanctions, yielded many consequences such as a sharp rise in rents and staples' prices, causing the decline and eventual squeeze of the middle class. Indeed, the last income decile, especially among rural people, benefited from receiving the cash subsidy. This is apart from the situation of about 2 million refugees living in Iran, who faced a staggering price increase, while the subsidy did not apply to them. That worsened their economic conditions and made them more marginalized.

It seems that facilitated integration of Iranian food regime into international corporate relations, same as lifted sanctions, did not last a long time. Despite the government's insistence on transferring some of the most important national companies, such as The Social Security Investment Company (Shasta), to the private sector (with provided reasons like improving management, curbing the corruption or bypassing the sanctions), its policies toward agro-food businesses and resources go against liberalization. Perhaps looking more closely at current 
subsidy and tariff policies of countries such as the US, China, and Canada raises the question if the neoliberalist economy and the global food regime are experiencing a transformation. In the globalized context where many local producers and farmers face unequal competition, and while climate change affects regions unevenly, many nations may increase their support of domestic production.

\section{Conflicts of Interest}

The authors declare no conflicts of interest regarding the publication of this paper.

\section{References}

[1] Pritchard, B. (2009) The Long Hangover from the Second Food Regime: A World-Historical Interpretation of the Collapse of the WTO Doha Round. Agriculture and Human Values, 26, 297-307. https://doi.org/10.1007/s10460-009-9216-7

[2] Alavi, S.J. (2010) Accession of Iran to the World Trade Organization: A Legal-Political Overview. Iranian Review of Foreign Affairs, 1, 137-159.

[3] McMichael, P. (2009) A Food Regime Analysis of the "World Food Crisis". Agriculture and Human Values, 26, 281-295. https://doi.org/10.1007/s10460-009-9218-5

[4] McMichael, P. (2009) A Food Regime Genealogy. The Journal of Peasant Studies, 36, 139-169. https://doi.org/10.1080/03066150902820354

[5] McMichael, P. (2013) Food Regimes and Agrarian Questions. Agrarian Change and Peasant Studies Series. Fernwood Books Ltd., Nova Scotia, 3. https://doi.org/10.3362/9781780448794.000

[6] Woertz, E. (2013) Historic Food Regimes and the Middle East. Food Security in the Middle East. C. Hurst and Co. Publishers, London. https://doi.org/10.1093/acprof:oso/9780199361786.003.0002

[7] Friedmann, H. (2016) Commentary: Food Regime Analysis and Agrarian Questions: Widening the Conversation. The Journal of Peasant Studies, 43, 671-692. https://doi.org/10.1080/03066150.2016.1146254

[8] Mohtadi, H. (1990) Rural Inequality and Rural-Push versus Urban-Pull Migration: The Case of Iran, 1956-1976. World Development, 18, 837-844. https://doi.org/10.1016/0305-750X(90)90006-I

[9] Rostow, W.W. (1990) The Stages of Economic Growth: A Non-Communist Manifesto. Cambridge University Press, Cambridge. https://doi.org/10.1017/CBO9780511625824

[10] Clark, B. (2015) Food Regimes and Agrarian Questions, by Philip McMichael. Halifax and Winnipeg: Fernwood Publishing, 2013. Pp. xii+ 196. \$18.95 (pb). ISBN 978-1552665756. Journal of Agrarian Change, 15, 296-298. https://doi.org/10.1111/joac.12098

[11] Chaifetz, A. and Jagger, P. (2014) 40 Years of Dialogue on Food Sovereignty: A Review and a Look Ahead. Global Food Security, 3, 85-91. https://doi.org/10.1016/j.gfs.2014.04.002

[12] Salami, H., Mohtashami, T. and Naeini, M.S.N. (2013) Prospects for Food Self-Sufficiency in Iran in 2025. Food Security in the Middle East. C. Hurst and Co. Publishers, London. https://doi.org/10.1093/acprof:oso/9780199361786.003.0005

[13] Babar, Z. (2014) Food Security in the Middle East. Oxford University Press, Oxford. 
https://doi.org/10.1093/acprof:oso/9780199361786.001.0001

[14] Kamrava, M., Babar, Z., Woertz, E., Harrigan, J., Bush, R., Salami, H., Pelat, F., et al. (2012) Food Security and Food Sovereignty in the Middle East. https://doi.org/10.2139/ssrn.2839219

[15] Amid, J. (2007) The Dilemma of Cheap Food and Self-Sufficiency: The Case of Wheat in Iran. Food Policy, 32, 537-552. https://doi.org/10.1016/j.foodpol.2006.11.001

[16] Donya-e-Eqtesad (2013) Iran's Major Export Items during the Qajar. 3086. http://donya-e-eqtesad.com/news/772225

[17] Araghi, F. (2003) Food Regimes and the Production of Value: Some Methodological Issues. The Journal of Peasant Studies, 30, 41-70. https://doi.org/10.1080/03066150412331311129

[18] Mansourbakht, G. (2009) Agricultural Trade in Qajar Period. Journal of Iran History, 61, 123-150.

[19] Wilson, R. (1979) The Economies of the Middle East. Springer, Berlin. https://doi.org/10.1007/978-1-349-03421-5

[20] Shakoori, A. (2006) Planning and Agricultural Development in Iran. Critique: Critical Middle Eastern Studies, 15, 265-282. https://doi.org/10.1080/10669920600997084

[21] Biazar, B. (2009) Learning and Activism: Iranian Women in Diaspora. ter's Thesis, Graduate Department of Adult Education and Counselling Psychology University of Toronto, Toronto.

[22] Bayat, A. (1994) Class, Historiography, and Iranian Workers. In: Lockman, Z., Ed., Workers and Working Classes in the Middle East. Struggles, Histories, Historiographies, State University of New York Press, New York, 165-210.

[23] Abrahamian, E. (2008) A History of Modern Iran. Cambridge University Press, Cambridge. https://doi.org/10.1017/CBO9780511984402

[24] Abrahamian, E. (1982) Iran between Two Revolutions. Princeton University Press, Princeton.

[25] Moghadam, F.E. (1996) From Land Reform to Revolution: The Political Economy of Agrarian Relations in Iran, 1962-1979 (Vol. 4). IB Tauris, London.

[26] Najmabadi, A. (1987) Land Reform and Social Change in Iran. University of Utah Press, Salt Lake City.

[27] Escobar, A. (2012) Encountering Development: The Making and Unmaking of the Third World. Princeton University Press, Princeton.

https://doi.org/10.1515/9781400839926

[28] Ellwood, W. (2015) No-nonsense Globalization: Buying and Selling the World. New Internationalist, Oxford.

[29] Hassim, S. and Razavi, S. (2006) Gender and Social Policy in A Global Context: Uncovering the Gendered Structure of "The Social”. In: Gender and Social Policy in a Global Context, Palgrave Macmillan, London, 1-39. https://doi.org/10.1057/9780230625280 1

[30] Crush, J. (1995) Power of Development. Psychology Press, London.

[31] Majd, M.G. (1992) On the Relationship between Land Reform and Rural-Urban Migration in Iran, 1966-1976. Middle East Journal, 46, 440-455.

[32] Amid, J. (2009) Land Reform in Post-Revolutionary Iran Revisited. Middle East Critique, 18, 73-87. https://doi.org/10.1080/10669920802685206 
[33] Annual OPEC Oil Prices 1960-2016 (2016) Statista. https://www.statista.com/statistics/262858/change-in-opec-crude-oil-prices-since-1 $\underline{960}$

[34] Gupta, S. (2000) Equity and Efficiency in the Reform of Price Subsidies: A Guide for Policymakers. International Monetary Fund, Washington DC.

[35] Laframboise, M.N., Alonso-Gamo, M.P., Feler, M.A., Bazzoni, M.S., Nashashibi, M.K.A. and Horvitz, S.P. (1998) Algeria: Stabilization and Transition to Market (No. 165). International Monetary Fund, Washington DC. https://doi.org/10.5089/9781557756916.084

[36] Aramian, R. (2013) Experts: The Rich Have Become Richer. Shargh, 1710. http://www.sharghdaily.ir/Modules/News/PrintVer.aspx?News Id=7833\&V News $\underline{\mathrm{Id} \& S r c=\text { Main }}$

[37] Tabnak (2015) The Recent Report of Gini Coefficient Index by the Central Bank. http://www.tabnak.ir/fa/news/463173

[38] Picotte, M.S. and Campbell, C.G. (2010) The Effects of War on Iraq's Food System: A Historical Analysis and Proposal for Future Direction. Journal of Hunger \& Environmental Nutrition, 5, 234-253. https://doi.org/10.1080/19320248.2010.489378

[39] Bush, R. and Martiniello, G. (2017) Food Riots and Protest: Agrarian Modernizations and Structural Crises. World Development, 91, 193-207. https://doi.org/10.1016/j.worlddev.2016.10.017

[40] Farsnews (2012) Investigating the Implementation of the Second Phase of Targeted Subsidy Plan by the Parliament. http://www.farsnews.com/printable.php?nn=13910205000575

[41] Taheri, M. (2014) Consequences of a Cursory Economic Surgery: Failure of the First Phase of Targeted Subsidy Plan in Reducing Fuel Consumption. http://www.irna.ir/fa/News/81054436

[42] Klein, N. (2007) The Shock Doctrine: The Rise of Disaster Capitalism. Macmillan, London.

[43] Guillaume, D. and Zytek, R. (2010) Islamic Republic of Iran: Selected Issues Paper. International Monetary Fund, Washington DC. 


\section{Appendix A}

\section{Cerals, total production}

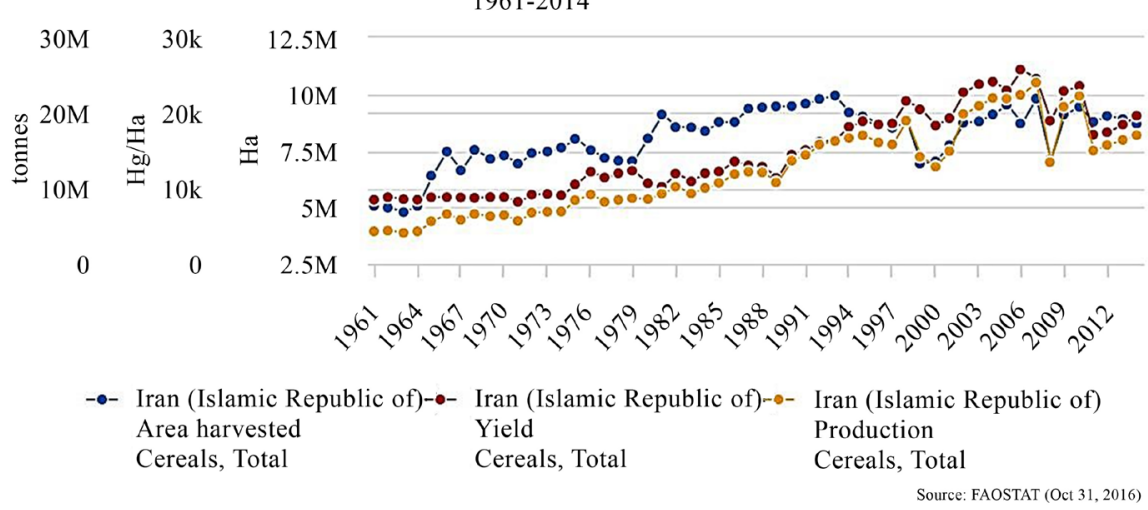

\section{Appendix B}

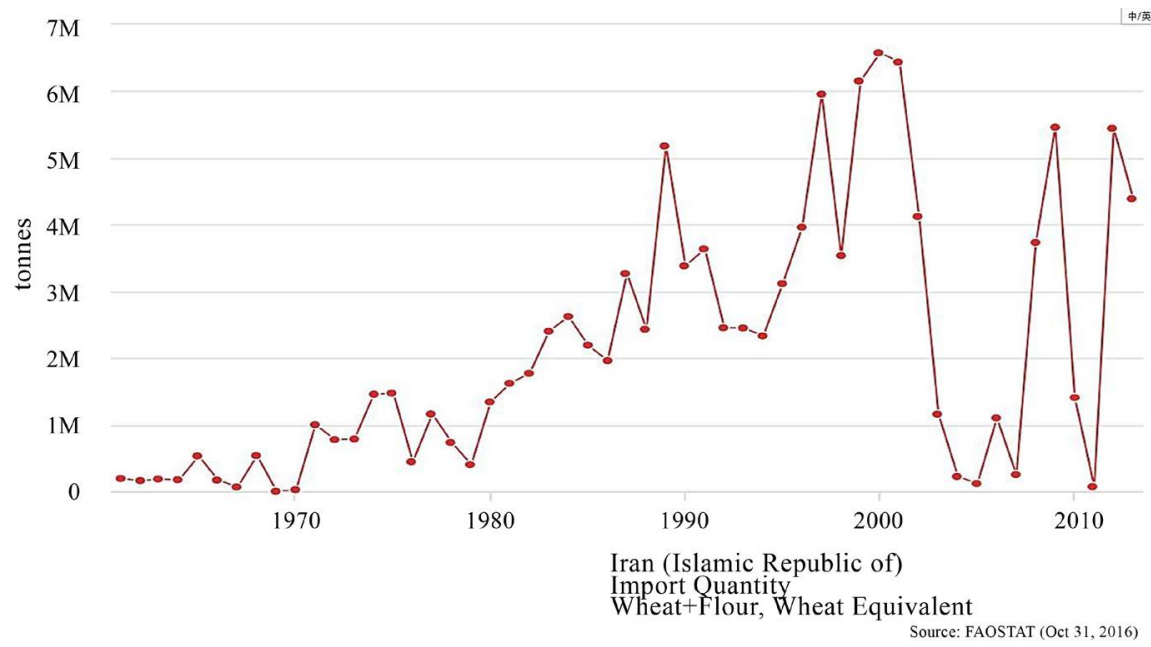

